\title{
PENGERING ENERGI SURYA UNTUK PENGERINGAN BAHAN PAKAIAN
}

\section{DRYER SOLAR ENERGY MATERIALS FOR DRYING CLOTHES}

\author{
Oleh: \\ Yuwana, B. Sidebang, dan Evanila Silvia \\ Jurusan Teknologi Pertanian Fakultas Pertanian Universitas Bengkulu
}

\begin{abstract}
This research based community service activity was conducted to solve the problem of clothes sun drying faced by students hosting in Orchid Dormitory, University of Bengkulu by introducing the further modified YSD-UNIB12 solar dryer. Strcture of dryer was $5 \mathrm{~m} \times 6$ $m$ in size equipped with $2 m \times 6 m$ drying cchamber having capacity of about 400 pieces of clothes. The dryer completed drying process of cloths made of nylon "sifon" and blouse in 3 hours, and woolen cloth in 4 hours, and synthetical socks in 5 hours. The modified YSDUNIB12 resulted better quality of dry cloth, saved time and space and minimised risk of clothes contamination. The dryer was successfully adopted by the dormitory management and inhabitants as very good solution of their their problem.
\end{abstract}

Keywords: Solar energy dryer, clothes, dormitory

\section{PENDAHULUAN}

Pengeringan bahan pakaian yang banyak dilakukan oleh masyarakat terutama yang berada di wilayah tropis adalah penjemuran. Cara pengeringan ini mudah dilakukan, luwes dan ekonomis tetapi mengalami banyak masalah. Beberapa masalah yang sering ditemui antara lain sebagai berikut. Penjemuran memerlukan tempat yang luas karena bahan yang dijemur membutuhkan akses langsung sinar matahari sehingga hal ini menimbulkan masalah terutama di kota yang biasanya pemukimannya padat dan harga tanahnya mahal. Karena sifatnya yang terbuka, bahan yang dijemur menjadi rawan terhadap kontaminasi baik kotoran maupun benda lain yang tidak dikehendaki. Penjemuran beresiko kehilangan bahan, baik karena terpaan angin, hujan maupun gangguan hewan maupun manusia. Penjemuran juga meresikokan bahan terhadap kerusakan akibat interaksi bahan dengan angin, air maupun benda-benda lain yang dapat menyebabkan rusak bahan baik secara fisik, kemis maupun biologis. Penjemuran juga memerlukan banyak tenaga untuk memindahkan bahan, terutama pada saat musim hujan.

Untuk mengatasi kendala tersebut Untuk mengatasi kendala ini pengering berenergi surya banyak dikembangkan dengan berbagai cara pemanfaatan energi dan karakteristiknya (Brooker et al., 1974, Patterson et al., 1971, McLean, 1980, Haque et al., 1982). Dalam satu dekade terakhir ini Jurusan Teknologi Pertanian Fakultas Pertanian Universitas Bengkulu telah berhasil mengembangkan beberapa model pengering tenaga surya. Alat pengering 
yang dikembangkan dieksplorasi untuk mengeringkan bermacam-macam produk pertanian. Yuwana (1999) dan Yuwana, 2002 mengembangkan pengeringan energi surya tidak langsung bermodel rumah kaca. Bagian terpenting alat pengering terdiri atas: kerangka kayu, kolektor panas, ruang pengering, cerobong dan kotak penyimpan panas. Kolektor terbuat dari kaca bening dan plenum yang berupa seng gelombang bercat hitam yang diletakkan di atas sebuah papan kayu. Prinsip kerja pengering ini adalah membuat perangkap panas semaksimum mungkin dan mengalirkannya secara otomatis melintasi bahan yang dikeringkan sehingga kadar air bahan teruapkan dari bahan dengan energi panas tersebut. Alat ini dapat menghasilkan suhu ruang pengering ini berkisar antara $37,8-55,8{ }^{\circ} \mathrm{C}(2-21$ ${ }^{\circ} \mathrm{C}$ lebih tinggi dari suhu udara luar). Pengering ini dapat menurunkan kadar air ikan ratarata dapat diturunkan dari 76,44\% menjadi 14,18\% dalam waktu 15 jam. Pengering tersebut mengalami berbagai modifikasi untuk digunakan produk lain seperti : sale pisang dan rengginang yang dapat mengeringkan produk dalam waktu 2-3 hari (Yuwana dan Mujiharjo, 2004); keripik pisang yang dapat menyelesaikan pengeringan 1-3 hari (Yuwana dan Mujiharjo, 2005), krupuk ikan dengan penyelesaian pengeringan 1-2 hari (Yuwana, 2006), sawi dengan prestasi dapat mempercepat pengeringan dalam pembuatan sawi asin lebih cepat 2 hari dibandingkan dengan penjemuran (Yuwana dkk., 2007). Yuwana (2009) menyempurnakan desain interior ruang pengering dengan merubah orientasi rak dan mencobakan alat pengering untuk pengeringan sale pisang di pengrajin sale pisang Raflesia Bengkulu. Hasil percobaan menunjukkan bahwa pengering dapat menyelesaikan proses pengeringan dengan dua kali lebih cepat dibandingkan dengan penjemuran yaitu 2-3 hari saja. Model yang terakhir in disempurnakan lagi desain cerobongnya dan melengkapinya dengan kipas isap menjadi pengering model teko bersayap mampu menyelesaikan pengeringan 1,83 kali lebih cepat dari penjemuran (Yuwana dkk., 2011). Pengering model teko disempurnakan lagi dengan membuat desain cerobong yang dapat menggantikan fungsi kipas sehingga pemakaian listrik bisa dihilangkan dan desain yang disempurnakan ini diberi nama model YSD-UNIB12. Model ini mampu menghasilkan suhu ruang pengering rata-rata $40-51{ }^{\circ} \mathrm{C}$ dan telah diujikan secara sukses untuk mengeringkan ikan (Yuwana, dkk., 2012), cabai, sawi dan daun singkong (Yuwana dan Silvia, 2012), ubi kayu (Silvia dan Yuwana, 2012).

Artikel ini menyajikan hasil kegiatan pengabdian yang bertujuan untuk mengkaji kinerja pengering energi surya model YSD-UNIB12 yang sudah disempurnakan dalam mengeringkan bahan pakaian di Asrama Orchid Universitas Bengkulu.

\section{METODE PENGABDIAN}

Penelitian dalam rangka pengabdian kepada masyarakat ini dilakukan dalam dua tahapan. Tahapan pertama adalah menyempurnakan pengering Model YSD-UNIB12 termodifikasi dan tahapan kedua adalah mengujinya untuk mengeringkan bahan pakaian. Penyempurnaan dilakukan dengan memperbesar ruang pengering dan meningkatkan kinerja kolektor panas Gambar 1 memperlihatkan foto pengering lengkap dengan bagian-bagian 
beserta ukurannya. Kerangka pengering terbuat dari baja ringan, berdinding dan beratap palstik UV $14 \%$ yang dilengkapi dengan cerobong yang secara keseluruhanmmenempati luasan $5 \times 6 \mathrm{~m}^{2}$. Bagian terpenting alat pengering terdiri atas: ruang pengering, cerobong dan kolektor panas. Ruang pengering dilengkapi 4 rel tempat gantungan pakaian pakaian yang dikeringkan. Cerobong membujur di bagian tengah menyatu dengan ruang pengering. Cerobong diberi outlet udara, memanjang di sisi kanan dan kiri dengan lebar $10 \mathrm{~cm}$ bagian atas cerong dan diberi atap. Kolektor mempunyai plenum berupa aluminium bergelombang hitam yang diletakkan di atas papan triplek, beratap plastik UV 14\% dan dilengkapi inlet. Kolektor ini berfungsi untuk menjerat panas dan mensuplaikannya ke ruang pengering.

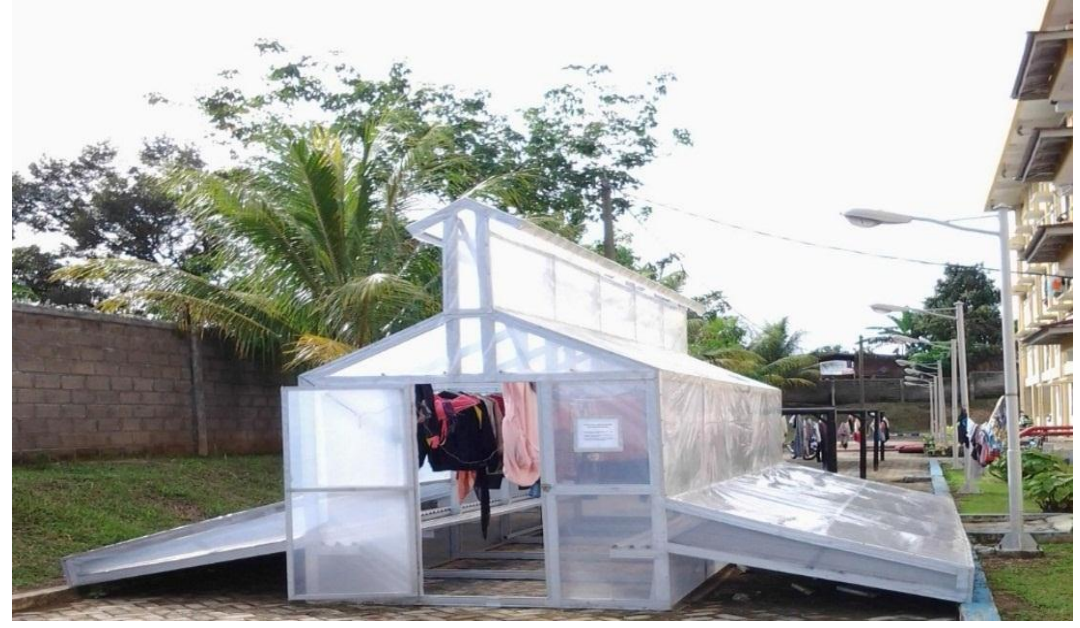

Gambar 1. Pengering lengkap dengan bagian-bagiannya

Prinsip kerja alat pengering ini adalah sebagai berikut. Bangunan pengering memanen panas dari matahari yang memanaskan udara dalam ruang pengering dan udara dalam plenum yang masuk melalui inlet udara. Karena adanya sistem tertutup maka di dalam pengering tercipta gradien tekanan udara yang cukup antara ruang pengering dan ruang kolektor dengan titik teratas di dalam cerobong. Dengan demikian terjadi aliran udara panas dari kolektor dan ruang pengering menuju cerobong. Aliran udara panas ini akan menguapkan air dalam bahan pakaian basah yang sudah terlebih dahulu diletakkan pada gantungan pakaian dan air dalam sepatu basah yang diletakkan di atas balai-balai. Udara yang telah membawa uap air ini akan keluar melalui outlet udara yang terdapat pada cerobong. Proses ini berlangsung terus menerus sampai bahan pakaian tersebut kering.

Kapasitas pengering adalah sekitas 400 potong pakaian dan pengering ini mempunyai keunggulan: tidak banyak memakan tempat; tertutup menjaga barang yang dikeringkan dari kotoran dan kontaminasi, menghindarkan barang dari kerusakan dan kehilangan, menghindarkan pemindahan produk selama pengeringan sehingga tidak menguras tenaga, membuat barang lebih cepat kering, mudah dioperasikan dan mudah dibuat dengan biaya terjangkau.

Pengujian pengering diakukan dengan menginstalasi pengering tersebut melintang arah datangnya matahari. Bahan pakaian yang diujikan masing-masing terbuat dari nilon, 
sifon, blus, wool dan kaos kaki sintetis. Tata cara pengujian adalah sebagai berikut. Bahan pakaian dicuci, diperas dan ditimbang untuk mengetahui berat awal bahan pakaian basah. Semua bahan pakaian dipasang pada penggantung dan selanjutnya penggantung dipasangkan pada rel. Pada saat pengujian pengering beroperasi pada kapasitas hampir penuh. Untuk membandingkan kinerja pengering dengan penjemuran digunakan sepasang kaos kaki, satu kaos kaki dikeringkan dalam pengering satu kaos kaki pasangannya dijemur di luar pengering. Pengamatan dilakukan mulai jam 09.00 WIB dengan mengukur temperatur dan kelembaban relatif ruang pengering dan udara luar dengan alat termohigrometer dan penimbangan secara periodik bahan pakaian selama proses pengeringan dan penjemuran.

\section{HASIL DAN PEMBAHASAN}

Hasil percobaan dituangkan dalam bentuk grafik hubungan antara temperatur, kelembaban relatif dan berat bahan pakaian dengan waktu pengamatan. Gambar 2 dan 3 masing-masing memperlihatkan grafik-grafik hubungan antara temperatur dan kelembaban relatif ruang pengering dan udara luar dengan jam pengamatan.



Gambar 2. Suhu ruang pengering disandingkan suhu udara luar

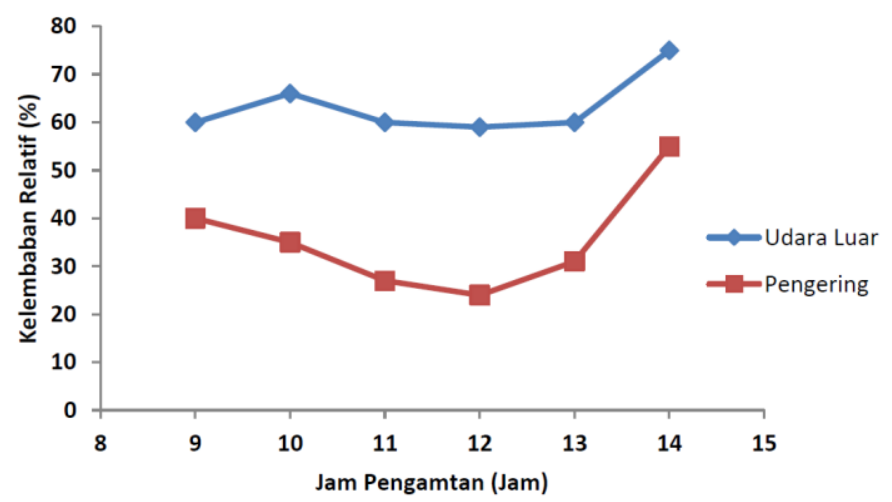

Gambar 3. Kelembaban relatif ruang pengering disandingkan dengan kelembaban relatif udara luar 
Gambar 2 menunjukkan bahwa suhu ruang pengering jauh lebih tinggi dibandingkan dengan suhu udara luar sebaliknya kelembaban relatif ruang pengering jauh lebih rendah dari kelembaban relatif udara luar seperti yang diperlihatkan Gambar 3. Keadaan ini yang memungkinkan pengering mampu menyelesaikan proses pengeringan lebih cepat Hasil pembandingan kinerja pengering dengan penjemuran dalam mengeringkan kaos kaki didemonstrasikan melalui proses pengeringan kaos kaki pada Gambar 4.

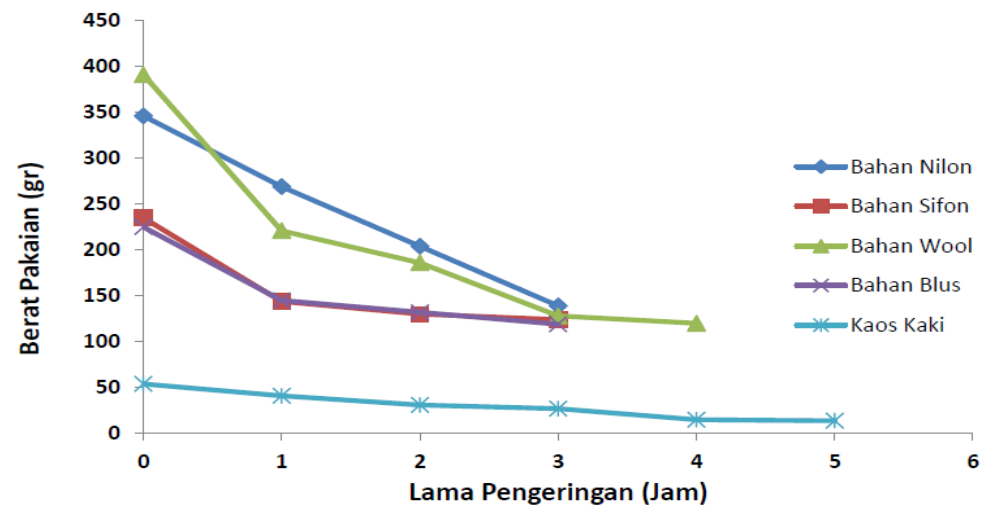

Gambar 4. Grafik pengeringan kaos kaki

Grafik pada gambar tersebut (warna merah) memperlihatkan bahwa waulupun berat awal kaos kaki yang dikeringkan dalam pengering lebih tinggi dari kaos kaki yang dijemur di udara luar tetapi kehilangan berat kaos kaki tersebut per satuan waktu lebih besar. Hal ini menbuktikan bahwa pengering mampu menghasilkan kecepatan pengeringan lebih besar atau menyelesaikan proses pengeringan lebih cepat. Hasil ini dipahami secara baik oleh mitra pengguna dan menyakinkan mereka bahwa mendapat manfaat dari aspek kecepatan penyelesaian pengeringan. Mitra juga dapat menyaksikan bahwa pakaian yang telah kering lebih rapi rapi dan terbebas dari debu dan kotoran lain.Kinerja pengeringan dalam menyelesaikan proses pengeringan pakaian yang dibuat dari jenis bahan yang berbeda diperlihatkan pada Gambar 5.

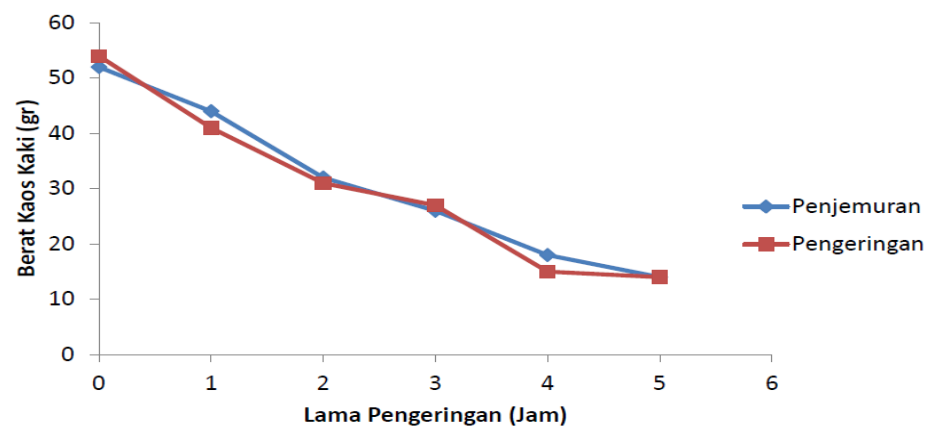

Gambar 5. Grafik-grafik pengeringan 5 jenis pakaian dari bahan yang berbeda 
Gambar 5 menunjukkan bahwa pengeringan pakaian dengan bahan nilon, sifon dan blus dapat diselesaiakan dalam waktu 3 jam sedangkan pengeringan pakaian bahan wool dan kaos kaki dapat diselesaiakan dalam waktu masing-masing 4 jam dan 5 jam.

Hasil yang terakhir ini memberikan petunjuk kepada pengguna terhadap waktu yang diperlukan untuk menyelesaian proses pengeringan pakaian dengan bahan yang berbeda. Dengan pengetahuan ini mereka dapat memperkirakan kapan pakaian dapat diambil dari pengering ketika mereka mengeringkan pakaian yang berbahan mirip dengan kelima bahan tersebut.Teramati juga bahwa yang dikeringkan dengan alat pengering juga terlihat lebih bersih dan rapi.

\section{KESIMPULAN DAN SARAN}

\section{Kesimpulan}

Berdasarkan hasil tersebut di atas dapat disimpulkan sebagai berikut. Pengering YSDUNIB12 termodifikasi dan disempurnakan serta diaplikasikan di Asrama Orchid Universitas Bengkulu. Pengering mempunyai ukuran total $5 \mathrm{~m}$ x $6 \mathrm{~m}$ dengan luas ruang pengering $2 \mathrm{~m}$ x 6 m yang dilengkapi 4 rel gantungan pakaian yang mampu menampung kurang lebih 400 potong pakaian. Pengering mampu menyelesaikan pengeringan pakaian dengan bahan nilon, sifon dan blus dalam waktu 3 jam sedangkan pengeringan pakaian bahan wool dan kaos kaki dapat diselesaiakan dalam waktu masing-masing 4 jam dan 5 jam. Pengering dapat menghasilkan pakaian kering yang lebih bersih dan rapi dibandingkan dengan pakaian kering hasil penjemuran. Pengeringan pakaian dengan alat pengering telah membebaskan mitra dari gangguan manusia maupun hewan, terkurasnya pikiran dan tenaga akibat gangguan hujan dan dirasakan sangat menghemat tempat. Penerapan pengering telah diterima dengan baik sebagai solusi persoalan pengeringan yang dihadapi oleh mitra selama ini.

\section{Saran}

Disarankan agar kegiatan pengabdian kepada masyarakat berbasis riset ini dapat dilanjutkan dengan menerapkan alat pengering YSD-UNIB12 termodifikasi yang sudah tersempurnakan untuk menjadi contoh penyelesaian yang dihadapi penghuni Asrama Orchid lantai IV dan V. Selanjutnya alat pengering versi terakhir ini dapat diadopsikan kepada masyarakat yang mempunyai persoalan yang sama, terutama di lingkungan asrama dan permukiman mahasiswa.

\section{DAFTAR PUSTAKA}

Silvia, E. dan Yuwana, 2012, Kinerja Prototipe Pengering Energy Surya Model YSDUNIB12 dalam Mengeringkan Singkong. Prosiding Seminar Nasional dengan tema: Menuju Pertanian Berdaulat, Bengkulu 12 September 2012, ISBN: 9786029071078. Halaman 263-270. 
Yuwana, 1999, Green House Solar Dryer untuk Pengeringan Ikan, Penelitian Dana DIPA. Yuwana, 2002, Pengering Bertenaga Matahari untuk Pengeringan Ikan, Seminar Nasional dengan tema "Potensi Pertanian Dalam Meningkatkan Pendapatan Asli Daerah", Medan 11-12 Juni 2002.

Yuwana dan S. Mujiharjo, 2004, Desain Pengering Tenaga Surya untuk Pengeringan Sale Pisang dan Rengginang, Penelitian Dana Kementrian Pemberdayaan Perempuan.

Yuwana dan S. Mujiharjo, 2005, Pengeringan Keripik Pisang dengan Menggunakan Pengering Tenaga Surya. Penelitian Dana Kementrian Pemberdayaan Perempuan.

Yuwana, 2006, Pengering Bertenaga Surya untuk Krupuk Ikan, Penelitian Mandiri.

Yuwana, Hidayat, L., dan Taupandri, 2007, Desain Pengering Tenaga Surya untuk Pengeringan Sawi pada Pembuatan Sawi Asin, Penelitian Mandiri.

Yuwana, 2009, Pengering Sungkup Bersayap untuk Pengeringan Sale Pisang. Penelitian Mandiri.

Yuwana, Sidebang, B., dan E. Silvia, 2011, Pengembangan Pengering Energi Surya Tipe Teko Bersayap Untuk Pengeringan Produk Pertanian, Hibah Penelitian Unggulan Universitas Bengkulu.

Yuwana, Sidebang, B. dan E. Silvia, 2012, Penyempurnaan Desain dan Strategi Instalasi di Lapangan Pengering Energi Surya Tipe Teko Bersayap, Hibah Penelitian Unggulan Universitas Bengkulu.

Yuwana dan E. Silvia, 2012, Penggunaan Pengering Energy Surya Model YSD-UNIB12 untuk Pengeringan Cabai Merah, Sawi dan Daun Singkong. Prosiding Seminar Nasional dengan tema: Menuju Pertanian Berdaulat, Bengkulu 12 September 2012, ISBN: 9786029071078. Halaman 145-152. 
80 Dharma Raflesia Unib Tahun XIV, Nomor 1 Juni 2016 